\title{
Impact of COVID-19 Pandemic on Air Pollution in Poland Based on Surface Measurements and Satellite Data
}

Special Issue:

Special Issue on COVID-19 Aerosol Drivers, Impacts and Mitigation (XV)

\section{OPEN ACCESS}

Received: July 31, 2020

Revised: March 18, 2021

Accepted: March 22, 2021

\section{${ }^{*}$ Corresponding Authors: \\ Haowen Yan \\ haowen2010@gmail.com \\ Mikalai Filonchyk \\ filonchyk.mikalai@gmail.com}

\section{Publisher:}

Taiwan Association for Aerosol Research

ISSN: $1680-8584$ print

ISSN: 2071-1409 online

\section{Copyright: The Author(s).} This is an open access article distributed under the terms of the Creative Commons Attribution License (CC BY 4.0), which permits unrestricted use, distribution, and reproduction in any medium, provided the original author and source are cited.

\author{
Mikalai Filonchyk ${ }^{1,2^{*}}$, Volha Hurynovich ${ }^{1,2}$, Haowen Yan $^{1,2^{*}}$ \\ ${ }^{1}$ Faculty of Geomatics, Lanzhou Jiaotong University, Lanzhou 730070, China \\ ${ }^{2}$ Gansu Provincial Engineering Laboratory for National Geographic State Monitoring, Lanzhou \\ 730070, China
}

\section{ABSTRACT}

Since its first detection in December 2019 in the Chinese city of Wuhan, the virus has become a global pandemic within just three months. The Polish government declared a state of emergency on March 14, 2020, which was connected with the adoption of a number of measures aimed to prevent the spread of the virus. These restrictive measures have led to improvements in air quality throughout the country. Therefore, evaluation of the reduction in anthropogenic emissions due to COVID-19 and related government measures to constrain its spread is crucial to define its impact on air pollution. During this study, aerosol optical depth (AOD) observations from the Moderate Resolution Imaging Spectroradiometer (MODIS) were used along with tropospheric $\mathrm{NO}_{2}$ and $\mathrm{SO}_{2}$ vertical column densities from TROPOspheric Monitoring Instrument (TROPOMI). The data on ground-based concentrations of pollutants ( $P M_{2.5}, \mathrm{PM}_{10}, \mathrm{NO}_{2}$ and $\mathrm{SO}_{2}$ ) obtained from air quality monitoring stations were also considered to assess changes in aerosols and air pollutants connected with the cessation of various kinds of anthropogenic and industrial activities due to preventive measures for COVID-19. In large cities of the country, the concentrations of $\mathrm{PM}_{2.5}, \mathrm{PM}_{10}$ and $\mathrm{NO}_{2}$ were reduced in the range from $-5.1 \%$ to $-35.5 \%$, from $-8.3 \%$ to $-33.1 \%$ and from $-0.4 \%$ to $-18.8 \%$. In addition, satellite data for $\mathrm{NO}_{2}$ and $\mathrm{SO}_{2}$ also indicate a decrease in concentration across the country by $-10.8 \%$ and $-25.6 \%$ during the COVID-19 restrictions period. The lockdown events may play a vital role as a potential solution to reduce air pollution in future as it may not be uncommon for governments to introduce deliberately selective hotspot lockdowns to control pollution levels.

Keywords: COVID-19, Pandemic, Poland, TROPOMI, MODIS

\section{INTRODUCTION}

The coronavirus disease (COVID-19), first detected at the end of December 2019 in Wuhan, Hubei province, has quickly spread first in China, and then within a month, to neighboring countries as well as South and North America and Europe. The World Health Organization (WHO) announced on March 11, 2020 that the spread of the new coronavirus has reached the stage of a pandemic, as most countries and all the continents have been infected, and cases have already been reported in 114 countries.

To prevent the spread of the virus, many countries have taken emergency public health measures to suppress this pandemic, with strict local and regional actions. This has led to a sharp decline in industrial and commercial activity, traffic on the roads and the movement of people. Despite negatively affecting economic growth, the decline in anthropogenic activity had a positive effect on the environment (Chakraborty and Maity, 2020; Somani et al., 2020; Yunus et al., 2020; Ye et al., 2021).

The favorable effects of the COVID-19 lockdown have led to significant reductions in atmospheric 
pollution in various countries across the world, such as China (Filonchyk et al., 2020b; Liu et al., 2020; Wang et al., 2020), India (Mahato et al., 2020; Siddiqui et al., 2020; Singh et al., 2020), Ecuador (Pacheco et al., 2020), Saudi Arabia (Anil et al., 2020), Spain (Baldasano, 2020), Iran (Broomandi et al., 2020), Russia (Ginzburg et al., 2020), France (Sbai et al., 2021), Bangladesh (Islam et al., 2021), United Kingdom (Jephcote et al., 2020). The improvements in air quality have been caused by significant reductions in the number of anthropogenic pollutants such as restrictions on road traffic and industrial activities during the COVID-19 pandemic. Therefore, an evaluation of the change in air quality in Poland is necessary for a global comparison, since the data for the countries of Eastern Europe are quite narrow or completely absent. New data can provide important recommendations for introducing measures or modifying existing strategies to improve air quality not only at the level of one country, but at the level of the whole region.

Poland, located in Eastern Europe, like many other countries, suffered from COVID-19. As of 7 February 2021, in Poland, 1,550,255 cases of COVID-19 including 39,087 deaths have been officially confirmed. The first case of COVID-19 was reported in Poland on March 4, 2020 in the small town of Cybinka, near the border with Germany. On March 14, 2020, a state of emergency was declared in Poland due to the epidemic, which, in particular, manifested in limitations of movement. In March, most service and commerce organizations were closed. Universities and schools were locked down and mass events were prohibited. On March 20, a pandemic was officially declared in Poland. Additional restrictions have been introduced to prevent the spread of COVID-19. The restrictions for movement have been tightened and since March 31, based on a government decree: people walking the streets must keep a distance of two meters, parks, boulevards, beaches, hairdressers and beauty salons are closed, and unaccompanied underaged are prohibited from leaving their homes. Despite the growing numbers of confirmed cases and many victims of COVID-19, the government decided in mid-April to adopt a policy of gradually easing the pandemic restrictions.

This study is aimed to determine whether the lockdown measures taken by the Polish government have had a positive impact on air quality. The dynamics of the ground-based concentrations of $\mathrm{PM}_{2.5}, \mathrm{PM}_{10}, \mathrm{NO}_{2}$ and $\mathrm{SO}_{2}$ in March and April 2020 were compared with the same periods in 2019. In addition, the TROPOspheric Monitoring Instrument (TROPOMI) and Moderate Resolution Imaging Spectroradiometer (MODIS) were used to assess the concentration levels of $\mathrm{NO}_{2}, \mathrm{SO}_{2}$ and aerosol optical depth (AOD). These results will help to find out if the air quality in the country has improved due to the lockdown introduced after the COVID-19 pandemic.

\section{MATERIALS AND METHODS}

\subsection{Study Area}

Poland is one of the largest states in Europe, with an area of 312.7 thousand $\mathrm{km}^{2}$ and a population of 37.7 million. It's located between Germany in the west and four Eastern European countriesRussia, Lithuania, Belarus and Ukraine in the east (Fig. 1). From the north it is washed by the Baltic Sea, in the south - along with the mid-altitude Sudetes and the Carpathians it borders on the inland Czech Republic and Slovakia. The length of the territory from north to south is $649 \mathrm{~km}$, and from east to west $-689 \mathrm{~km}$. The administrative division of Poland includes 16 voivodeships.

Daily satellite (AOD, $\mathrm{NO}_{2}$ and $\left.\mathrm{SO}_{2}\right)$ and surface $\left(\mathrm{PM}_{2.5}, \mathrm{PM}_{10}, \mathrm{NO}_{2}\right.$ and $\left.\mathrm{SO}_{2}\right)$ data were acquired and processed for each period of national isolation introduced in Poland as measures to constrain the spread of COVID-19. For a more in-depth understanding of changes in pollutant concentrations, the data were classified in two-week periods: Period 1 (1-14 March; before lockdown), Period 2 (15-28 March; during lockdown), Period 3 (29 March-11 April; during lockdown), and Period 4 (12-25 April; after lockdown) and analyzed using simple mathematics and statistics. The average data of each pollutant for 2019 was also used to reveal the absolute differences with the lockdown periods in 2020.

\subsection{MODIS Data}

The Moderate Resolution Imaging Spectroradiometer (MODIS) satellite sensor is used to obtain daily AOD over Poland. AOD data were obtained from the MCD19A2 V6 data product is a MODIS Terra and Aqua combined Multi-angle Implementation of Atmospheric Correction (MAIAC) 


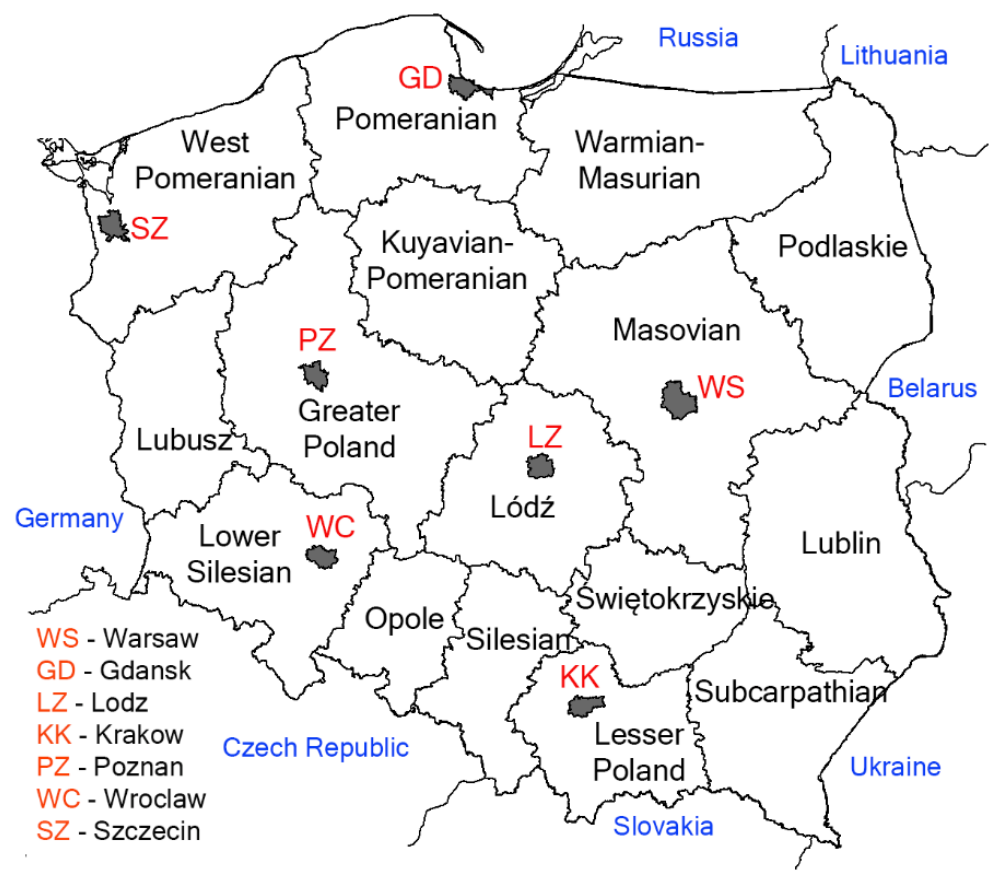

Fig. 1. Location of the study site.

Land Aerosol Optical Depth (AOD) gridded Level 2 product at a wavelength of $0.55 \mu \mathrm{m}$ produced daily at $1 \mathrm{~km}$ resolution (Lyapustin et al., 2018). The MAIAC AOD product (MCD19A2) was downloaded from NASA's Level-1 and Atmosphere Archive and Distribution System (LAADS) Distributed Active Archive Center (DAAC) (https://ladsweb.nascom.nasa.gov).

\subsection{TROPOMI/Sentinel-5p Data}

The TROPOspheric Monitoring Instrument (TROPOMI) on board the European Space Agency's Sentinel-5P satellite gathers the data needed to assess air quality. TROPOMI is a multispectral sensor that records the reflectance of wavelengths important for measuring atmospheric concentrations of $\mathrm{SO}_{2}, \mathrm{NO}_{2}, \mathrm{CH}_{4}, \mathrm{CO}, \mathrm{O}_{3}, \mathrm{CH}_{2} \mathrm{O}$ and aerosols (Veefkind et al., 2012). Until August 6,2019 , the spatial resolution of TROPOMI was $7 \times 3.5 \mathrm{~km}$ for $\mathrm{NO}_{2}$ and $\mathrm{SO}_{2}$. After that, the spatial resolution was updated to $5.5 \times 3.5 \mathrm{~km}$ with a wide swath of about $2600 \mathrm{~km}$, with daily global coverage. TROPOMI Level $2 \mathrm{NO}_{2}$ and $\mathrm{SO}_{2}$ dates were downloaded from the Copernicus Open Access Hub platform.

\subsection{Ground-based Data}

Ground-based measurements of $\mathrm{PM}_{2.5}, \mathrm{PM}_{10}, \mathrm{NO}_{2}$ and $\mathrm{SO}_{2}$ were obtained from air quality monitoring stations located in major cities in Poland operated by the Chief Inspectorate of Environmental Protection in March and April 2020. In total, data from 32 air quality monitoring stations which provide systematic measurements of air pollution in residential, industrial and rural areas, were used.

\subsection{Meteorology}

The chemical composition of the atmosphere, weather and climate are closely related. Climate variability and change have consequence for the chemical composition of the atmosphere by modifying factors that influence the life cycle (sources, transport, chemical/physical transformation and removal) of a pollutant in the atmosphere, such as temperature, cloud cover, precipitation, etc. mixing properties of the boundary layer (Liu et al, 2020). The meteorology data consisted of total precipitation rate $\left(\mathrm{kg} \mathrm{m}^{-2} \mathrm{~s}^{-1}\right)$, near surface wind speed $\left(\mathrm{m} \mathrm{s}^{-1}\right)$ and near surface air temperature $\left({ }^{\circ} \mathrm{C}\right)$, which were from the NASA Global Land Data Assimilation System Version 2 (GLDAS-2) with spatial resolution $0.25^{\circ}$ (Rodell et al., 2004). The modeling period is from 1 March to 30 April 2019 and 2020. Data on meteorological parameters are provided in Supplementary Materials (Figs. S1-S3). 


\section{RESULTS AND DISCUSSION}

\subsection{Aerosol Optical Depth (AOD) Observation by MODIS}

Average AODs during the lockdown period were lower than the average AODs for the same period in 2019 (Fig. 2). The analysis shows that in all regions of the country there was a decrease in AOD. This may be due to the restrictions imposed in many sectors of the economy in the battle against COVID-19, which led to changes in the sources of aerosols (emissions from various kinds of anthropogenic activities, electricity production, biomass combustion and vehicles) (Filonchyk et al., 2020b). Manufacturing and mining were the only sectors of the economy not subjected to restrictions (Krzysztofik et al., 2020). When considering the spatial-temporal variation of AOD in certain regions of the country (Fig. 3), it can be seen that the greatest decrease was observed during Period 3 in Opole (-67.5\%) and Masovianc (-66.7\%), followed by Podlaskie (-60.0\%), tódź (-55.6\%) and Lublin Voivodeships $(-52.8 \%)$. During Period 4, the largest declines were in Świętokrzyskie $(-36.4 \%)$, West Pomeranian $(-33.3 \%)$ and Subcarpathian Voivodeships $(-32.0 \%)$. There was a general decrease in AOD across the country by $-47.9 \%$ (Period 3 ) and $-20.3 \%$ (Period 4 ). At the same time, during the lockdown, the AOD values varied from 0.1 to 0.25 (Table S1). It is worth to state that the overall decrease in AOD confirms the positive impact of lockdown on air quality. The observed decline in AOD across the country during lockdown could be connected not only to reduced vehicle emissions, but also to reduced international and local bus traffic and large flight cancellations. The temporary suspension of international (from March 15) and domestic (from March 16) air travelling by the Polish government has led to a significant reduction of traffic in Polish aerospace. In 2020, air traffic decreased by 56.4\% compared to 2019 (Sas, 2021).

A similar situation was registered in the largest cities of the country, where a downward trend in AOD was observed (Table 1). This indicates that the nationwide lockdown covers all regions of the country. It is worth mentioning that during Period 1 and Period 2 of 2020, both in cities and in the country as a whole, AOD levels were higher compared to 2019. This is probably due to unfavorable meteorological factors that can affect the accumulation of pollutants in the atmosphere (Suhaimi et al., 2020; Hoang and Tran, 2021). Less precipitation and a lower temperature was recorded in March 2020, compared to the same period in 2019. This, as well as low wind speeds (Figs. S1-S3), combined with persistent anthropogenic emissions (space heating during colder seasons) can result in higher AOD values.

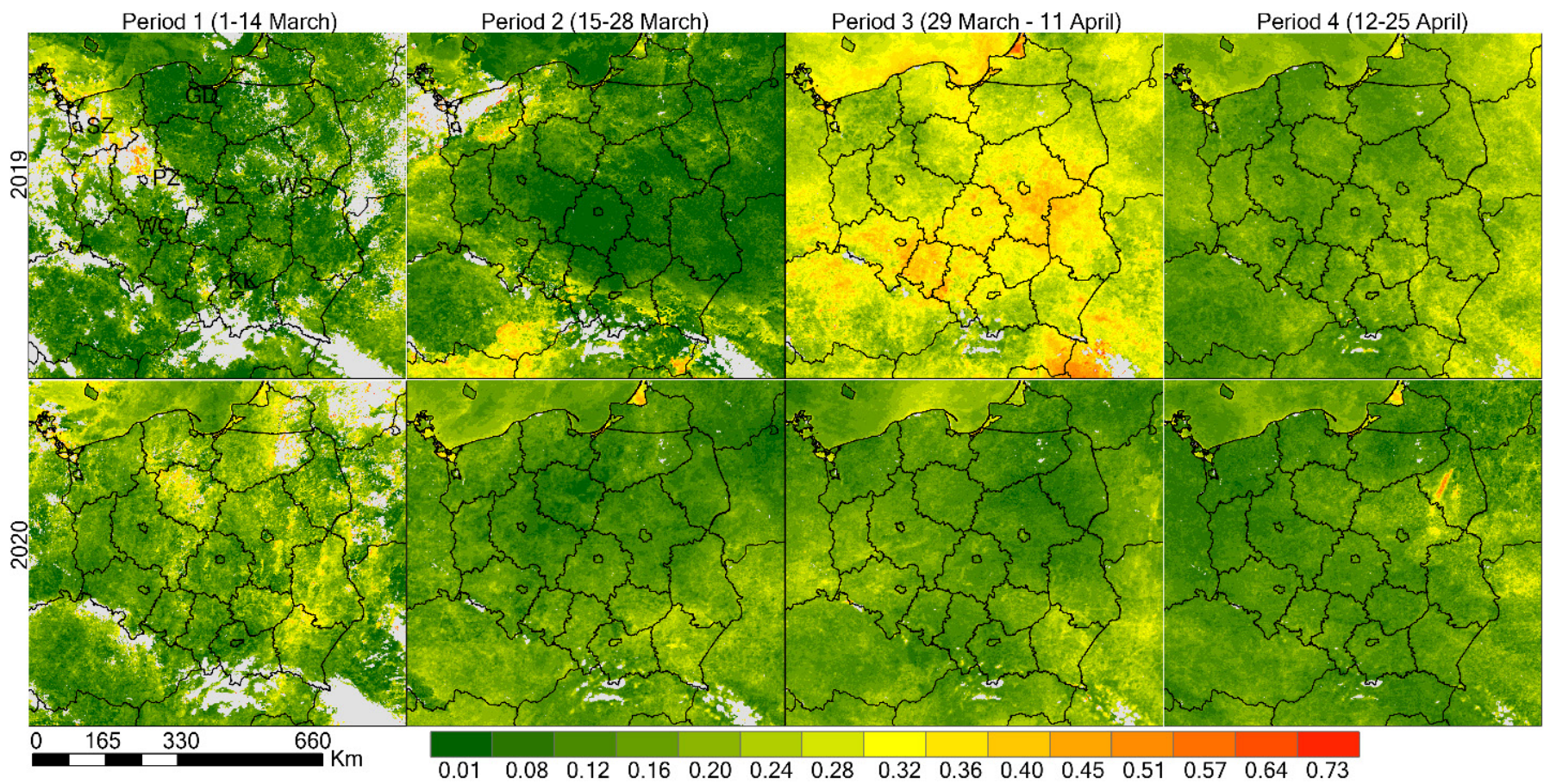

Fig. 2. Changes in aerosol optical depth (AOD) over Poland during 4 periods 2019 and 2020. 

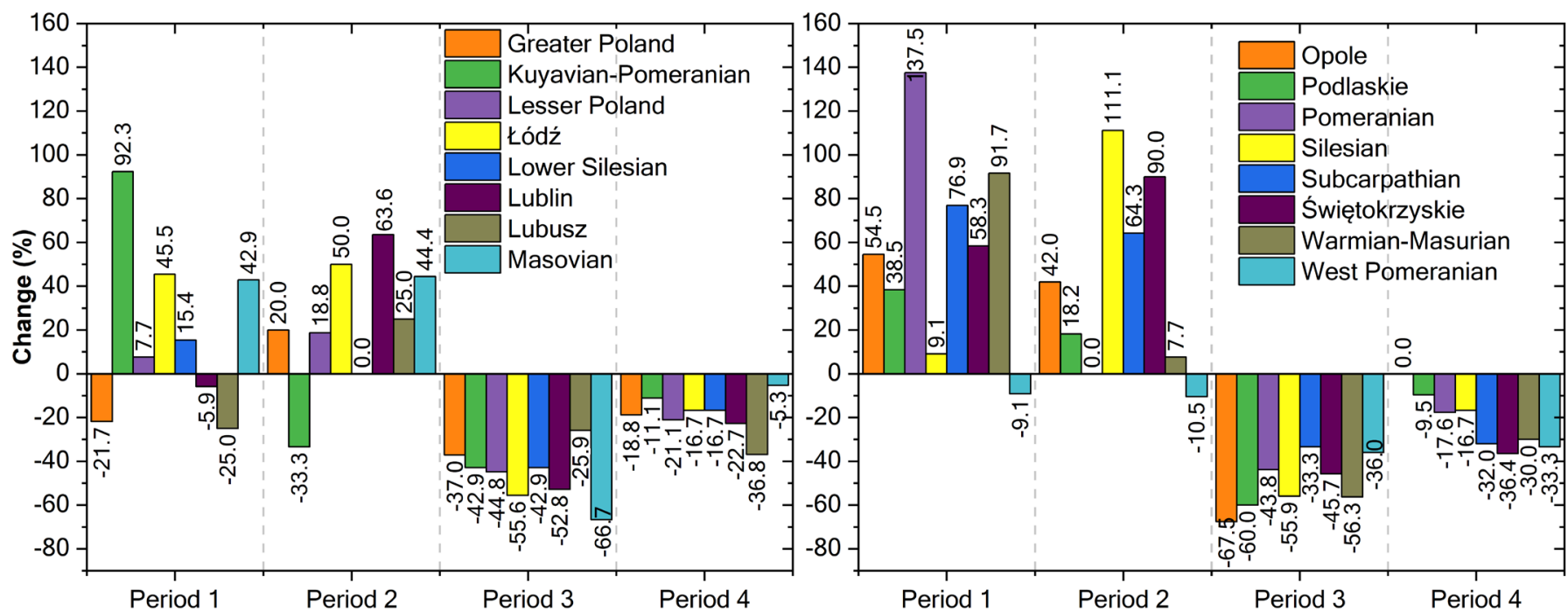

Fig. 3. Percentage change of aerosol optical depth during COVID-19 pandemic compared with same periods in 2019 and 2020.

Table 1. The AOD levels and relative change (\%) of AOD at major cities in Poland before, during and after lockdown.

\begin{tabular}{|c|c|c|c|c|c|c|c|c|c|c|c|c|}
\hline & \multicolumn{4}{|c|}{2019} & \multicolumn{4}{|c|}{2020} & \multicolumn{4}{|c|}{ Relative change (\%) } \\
\hline & Period 1 & Period 2 & Period 3 & Period 4 & Period 1 & Period 2 & Period 3 & Period 4 & Period 1 & Period 2 & Period 3 & Period 4 \\
\hline Krakow & 0.13 & 0.15 & 0.33 & 0.21 & 0.1 & 0.22 & 0.16 & 0.16 & -23.1 & 46.7 & -51.5 & -23.8 \\
\hline Lodz & 0.08 & 0.1 & 0.37 & 0.19 & 0.12 & 0.16 & 0.15 & 0.17 & 50.0 & 60.0 & -59.5 & -10.5 \\
\hline Poznan & - & 0.09 & 0.32 & 0.2 & 0.14 & 0.12 & 0.19 & 0.13 & - & 33.3 & -40.6 & -35.0 \\
\hline Wroclaw & 0.12 & 0.16 & 0.39 & 0.17 & 0.17 & 0.15 & 0.22 & 0.17 & 41.7 & -6.3 & -43.6 & 0.0 \\
\hline Warsaw & 0.09 & 0.06 & 0.37 & 0.18 & 0.19 & 0.15 & 0.15 & 0.16 & 111.1 & 150.0 & -59.5 & -11.1 \\
\hline Gdansk & 0.1 & 0.19 & 0.33 & 0.22 & 0.28 & 0.28 & 0.22 & 0.14 & 180.0 & 47.4 & -33.3 & -36.4 \\
\hline Szczecin & - & - & - & - & - & - & - & - & - & - & - & - \\
\hline
\end{tabular}

\subsection{Nitrogen Dioxide $\left(\mathrm{NO}_{2}\right)$ Observation by Sentinel-5P/TROPOMI}

Nitrogen dioxide $\left(\mathrm{NO}_{2}\right)$ play a key role in atmospheric chemistry and are a precursors to a number of harmful secondary air pollutants. $\mathrm{NO}_{2}$, along with other nitrogen oxides and non-methane hydrocarbons (NMHC), can contribute to the formation of photochemical smog (Sher, 1998). The absolute mixing ratios and their relation $\mathrm{NO}_{\times} / \mathrm{NMHC}$ (and the composition of $\mathrm{NMHCs}$ ) control the production of oxidants (especially $\mathrm{O}_{3}$ ).

The main anthropogenic activities that cause $\mathrm{NO}_{2}$ emissions include power generation, oil and gas extraction as well as smelting (McGonigle et al., 2004; Paraschiv and Paraschiv 2019; Biswas et al., 2020). $\mathrm{NO}_{2}$ is produced during power generation if burned coal contains sulfur impurities that are not removed out of plant's flue gas dusts. Also, $\mathrm{NO}_{2}$ is mainly emitted from the combustion of fossil fuels (diesel, gasoline, coal) emitted from car exhaust pipes and chimneys during power generation (Sher, 1998; Anttila et al., 2011; Melkonyan and Kuttle, 2012). Therefore, changes in the level of $\mathrm{NO}_{2}$ in the atmosphere can be used as an indicator of changes in human activity. $\mathrm{NO}_{2}$ changes can be estimated by comparing $\mathrm{NO}_{2}$ satellite data during the isolation period with similar periods last year. However, it should be noted that the interpretation of satellite $\mathrm{NO}_{2}$ data is not the same as the concentration observed at the ground level. $\mathrm{NO}_{2}$ levels are influenced by dynamic and chemical processes in the atmosphere. The concentration of $\mathrm{NO}_{2}$ in the atmosphere can vary due to changes in the weather, which affects both the lifespan of $\mathrm{NO}_{2}$ molecules and their spread by the wind (Schindler et al., 2020). It is also important to mention that satellites observing $\mathrm{NO}_{2}$ cannot monitor through clouds. Therefore, all the data shown is applicable only for days with low clouds level.

Data from the Sentinel-5P satellite show a decrease in $\mathrm{NO}_{2}$ concentration level over the entire territory of Poland (Fig. 4). This decline is particularly noticeable in the southern and western regions of the country, which coincides with a nationwide lockdown to prevent the spread of the coronavirus. 

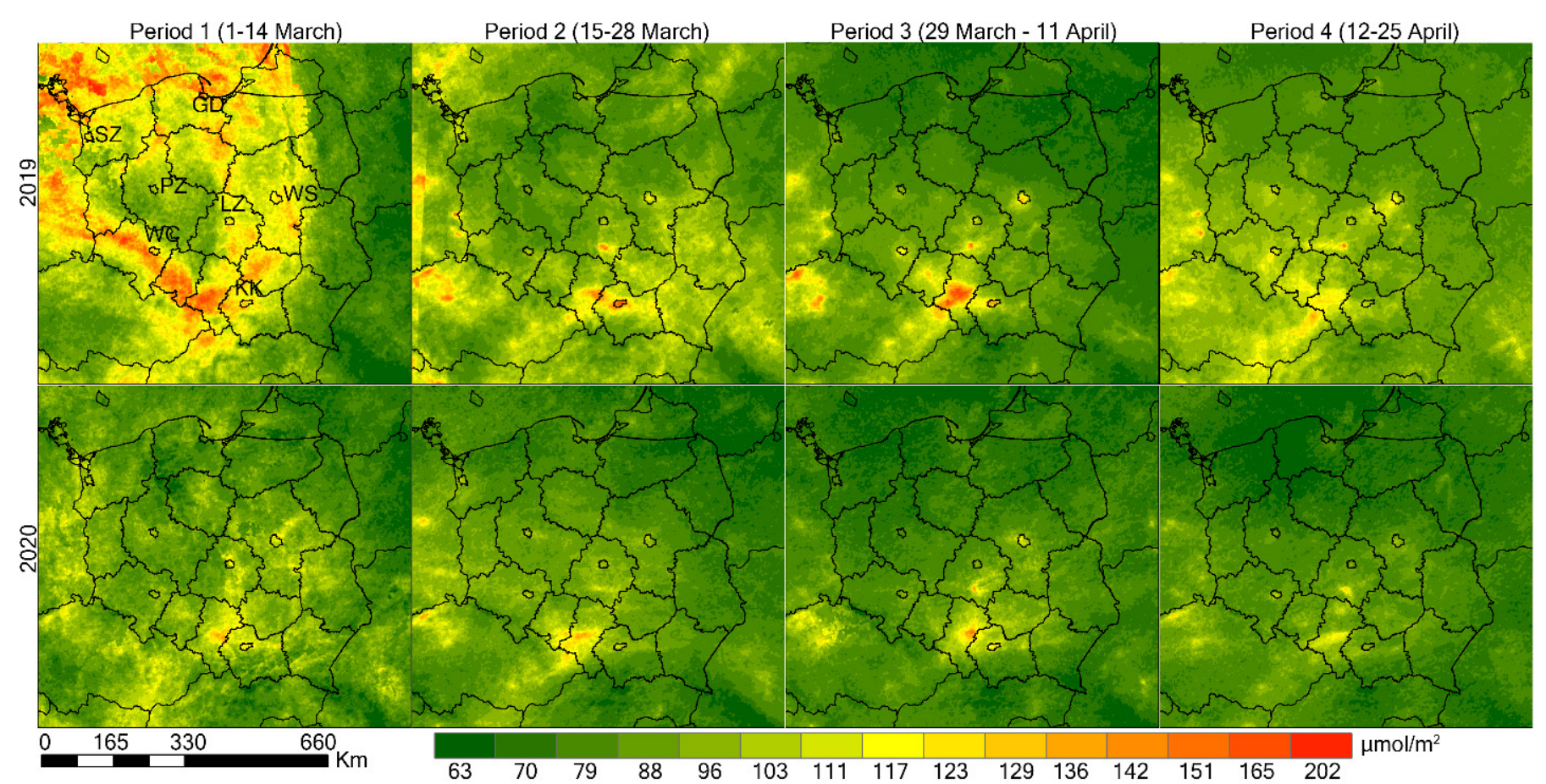

Fig. 4. Changes in tropospheric $\mathrm{NO}_{2}$ concentrations over Poland from 4 periods in 2019 and 2020.

Such changes were expected, since these areas and cities are the most industrialized in Poland. The overall decrease in $\mathrm{NO}_{2}$ concentration in 2020 was $-10.8 \%$ compared to the same period in 2019. At the same time, the largest reductions were during Period $1(-17.6 \%)$ and Period $4(-13.8 \%)$.

Tight restrictions are an important factor in the significant reduction in $\mathrm{NO}_{2}$ concentrations in the country. Fig. 5 shows that in many regions of the country there was a decrease in $\mathrm{NO}_{2}$ compared to the previous year. The largest decrease was recorded in Kuyavian-Pomeranian, Opole, WarmianMasurian and West Pomeranian Voivodeships, with tropospheric $\mathrm{NO}_{2}$ concentrations ranging from 65 to $96 \mu \mathrm{mol} \mathrm{m}{ }^{-2}$ (Table S2) depending on the region of the country during the lockdown (Period 3). In large cities of the country, a noticeable decrease in $\mathrm{NO}_{2}$ concentration was also observed (Table 2). These results correlate with recent studies from different regions of the world such as India, China, Ecuador, Spain, Malaysia, Germany, which indicate a decrease in $\mathrm{NO}_{2}$ concentration during the COVID-19 lockdown compared to the days before it (Baldasano, 2020; Filonchyk et al., 2020b; Pacheco et al., 2020; Siddiqui et al., 2020; Suhaimi et al., 2020; Burns et al., 2021).

\subsection{Sulfur Dioxide $\left(\mathrm{SO}_{2}\right)$ Observation by Sentinel-5P/TROPOMI}

While some of the $\mathrm{SO}_{2}$ in the atmosphere is generated by natural processes, a significant amount is formed by anthropogenic activity, mainly in power plants that burn fossil fuels (Li et al., 2018; Kaczmarczyk et al., 2020). Fig. 5 shows that in almost all regions of the country there was a decrease in $\mathrm{SO}_{2}$ concentration level during the isolation period. The most significant declines were in Greater Poland (-42.8\%), Łódź (-48.2\%) and Świętokrzyskie (-48.6\%) Voivodeships. At the same time, across the whole country, there was a decrease in $\mathrm{SO}_{2}$ by $-25.6 \%$. Although the outbreak of COVID-19 and the subsequent lockdown led to significant reductions in $\mathrm{SO}_{2}$ emissions due to the suspension of some production processes and a decrease in the number of cars on the roads, nonetheless, coal-fired power plants and some types of industries could make a significant contribution to air pollution. It is worth mentioning that the installed overall capacity of the Polish electricity system in 2019 was 46,799 MW. The share of installed capacity for coal and lignite was $67 \%(31,541 \mathrm{MW})$ and only $5.7 \%(2,788 \mathrm{MW})$ for natural gas. This indicates the dominance of coal-fired power plants in the country's energy sector. Moreover, Poland, along with Germany, burns more coal than other Western European countries (Osička et al., 2020). Also due to recommendations to stay at home, there was an increase in electricity consumption 

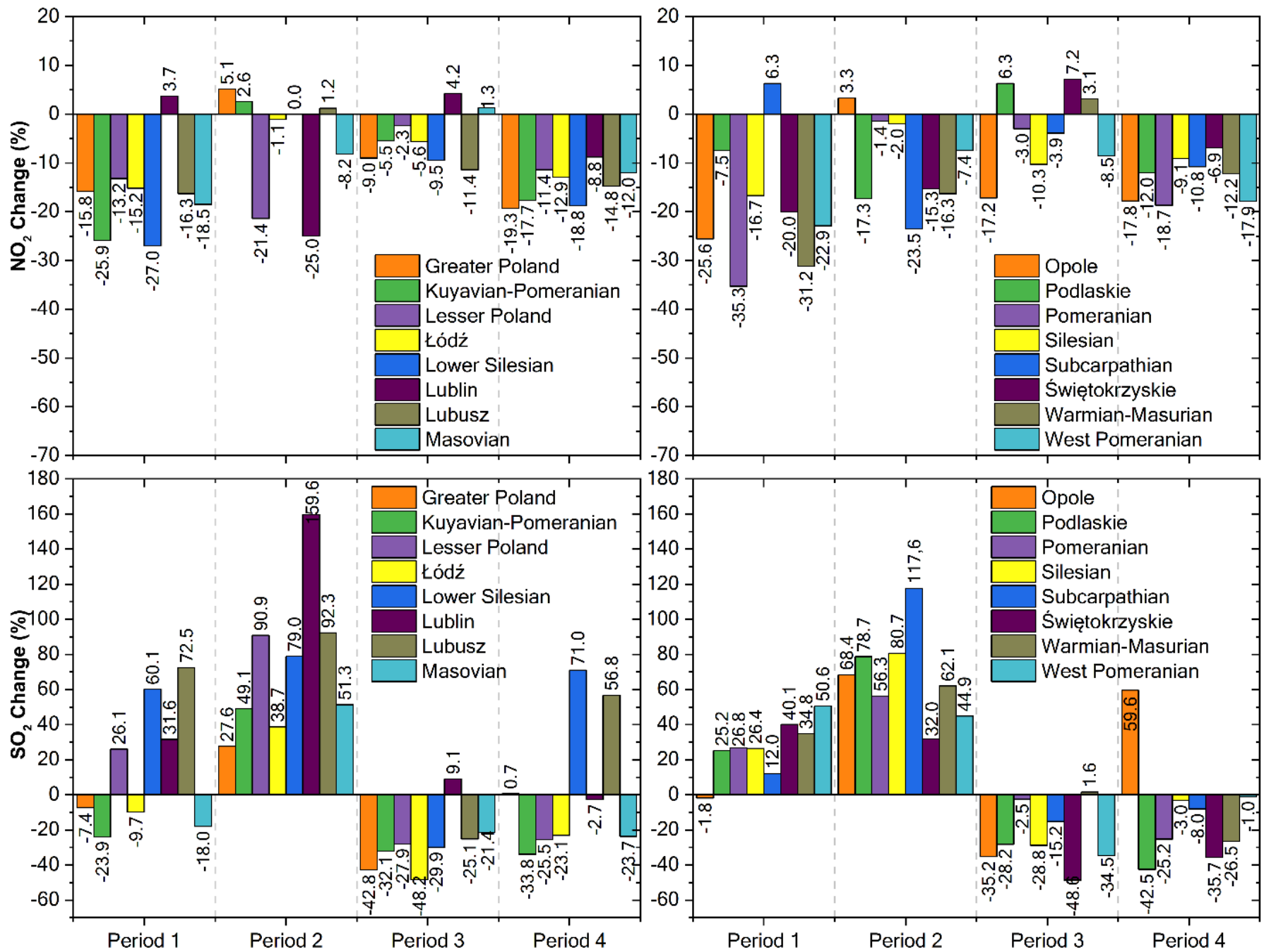

Fig. 5. Percentage change of $\mathrm{NO}_{2}$ and $\mathrm{SO}_{2}$ observed from the Sentinel-5P during COVID-19 pandemic compared with same periods in 2019 and 2020.

Table 2. Tropospheric $\mathrm{NO}_{2}$ concentrations $\left(\mu \mathrm{mol} \mathrm{m}{ }^{-2}\right.$ ) and relative change (\%) over major cities in Poland before, during and after lockdown.

\begin{tabular}{|c|c|c|c|c|c|c|c|c|c|c|c|c|}
\hline & \multicolumn{4}{|c|}{2019} & \multicolumn{4}{|c|}{2020} & \multicolumn{4}{|c|}{ Relative change (\%) } \\
\hline & Period 1 & Period 2 & Period 3 & Period 4 & Period 1 & Period 2 & Period 3 & Period 4 & Period 1 & Period 2 & Period 3 & Period 4 \\
\hline Krakow & 122 & 141 & 122 & 97 & 114 & 99 & 114 & 89 & -6.6 & -29.8 & -6.6 & -8.2 \\
\hline Lodz & 113 & 96 & 98 & 98 & 103 & 94 & 86 & 84 & -8.8 & -2.1 & -12.2 & -14.3 \\
\hline Poznan & 96 & 85 & 89 & 98 & 93 & 93 & 77 & 80 & -3.1 & 9.4 & -13.5 & -18.4 \\
\hline Wroclaw & 122 & 92 & 108 & 104 & 90 & 95 & 87 & 93 & -26.2 & 3.3 & -19.4 & -10.6 \\
\hline Warsaw & 116 & 104 & 110 & 103 & 105 & 93 & 101 & 89 & -9.5 & -10.6 & -8.2 & -13.6 \\
\hline Gdansk & 129 & 85 & 76 & 80 & 76 & 81 & 78 & 74 & -41.1 & -4.7 & 2.6 & -7.5 \\
\hline Szczecin & 113 & 101 & 87 & 90 & 99 & 95 & 74 & 76 & -12.4 & -5.9 & -14.9 & -15.6 \\
\hline
\end{tabular}

on cold days. Increased demand has forced power plants to generate more electricity, leading to increased $\mathrm{SO}_{2}$ emissions. Located in Opole and Lower Silesian Voivodeships Opole and Turow coal-fired Power Plants with generation capacity of 3,332 MW and 2,106 MW could have influenced the increase in $\mathrm{SO}_{2}$ by $59.6 \%$ and $71 \%$ during Period 4 .

The study showed that despite having a decrease in $\mathrm{SO}_{2}$ concentration throughout the country, there was a significant increase in $\mathrm{SO}_{2}$ concentrations in many individual cities studied, with the exception of Poznan $(-2.1 \%)$ and Gdansk $\left(-20.3 \%\right.$ ) (Table 3). The increase in $\mathrm{SO}_{2}$ concentration 
Table 3. The column density of $\mathrm{SO}_{2}$ concentration $\left(\times 10^{-6} \mathrm{~mol} \mathrm{~m}^{-2}\right)$ and relative change (\%) over major cities in Poland before, during and after lockdown.

\begin{tabular}{|c|c|c|c|c|c|c|c|c|c|c|c|c|}
\hline & \multicolumn{4}{|c|}{2019} & \multicolumn{4}{|c|}{2020} & \multicolumn{4}{|c|}{ Relative change (\%) } \\
\hline & Period 1 & Period 2 & Period 3 & Period 4 & Period 1 & Period 2 & Period 3 & Period 4 & Period 1 & Period 2 & Period 3 & Period 4 \\
\hline Krakow & 530 & 546 & 351 & 492 & 1053 & 1152 & 491 & 282 & 98.7 & 111.0 & 39.9 & -42.7 \\
\hline Lodz & 114 & 1030 & 275 & 292 & 581 & 985 & 378 & 438 & 409.6 & -4.4 & 37.5 & 50.0 \\
\hline Poznan & 322 & 932 & 470 & 165 & 709 & 1012 & 460 & 401 & 120.2 & 8.6 & -2.1 & 143.0 \\
\hline Wroclaw & 495 & 452 & 270 & 299 & 707 & 985 & 461 & 313 & 42.8 & 117.9 & 70.7 & 4.7 \\
\hline Warsaw & 486 & 1041 & 269 & 410 & 528 & 1474 & 543 & 220 & 8.6 & 41.6 & 101.9 & -46.3 \\
\hline Gdansk & 940 & 621 & 492 & 705 & 289 & 1020 & 392 & 445 & -69.3 & 64.3 & -20.3 & -36.9 \\
\hline Szczecin & 407 & 403 & 514 & 189 & 654 & 1432 & 644 & 395 & 60.7 & 255.3 & 25.3 & 109.0 \\
\hline
\end{tabular}

can be related to uncontrolled or partially controlled industrial and automotive activities in large cities, even during the isolation. It is also likely that power plants in other countries were still operating at full capacity due to the heating season, so transboundary transport of air pollutants may have an impact on changing pollutant concentrations (Halkos and Tsilika, 2019; Lai and Brimblecombe, 2021).

\subsection{Ground-based Concentrations of Air Pollutants}

The seven largest cities in the country were selected to study the ground-based concentration of pollutants $\left(\mathrm{PM}_{2.5}, \mathrm{PM}_{10}, \mathrm{NO}_{2}\right.$ and $\left.\mathrm{SO}_{2}\right)$. Hourly data for each pollutant was obtained from 32 air quality monitoring stations. Table 4 shows the average concentrations of the main pollutants in the atmosphere and their percentage changes monitored in each city during and after lockdown, compared to the same period in 2019.

As can be seen from Table 4, in all the cities there was an improvement in air quality during and after lockdown (Period 3 and Period 4). The most notable reductions were found for $\mathrm{PM}_{2.5}$, $\mathrm{PM}_{10}$ and $\mathrm{NO}_{2}$, as concentrations of these pollutants decreased in almost all the cities during and after the lockdown. During the lockdown, the highest level of $\mathrm{PM}_{2.5}, \mathrm{PM}_{10}$ and $\mathrm{NO}_{2}$ emission reductions was observed in Szczecin $(-35.5 \%,-32.3 \%$ and $-3.2 \%)$, followed by Poznan $(-25.0 \%$, $-26.6 \%$ and $10.7 \%)$. Wroclaw $(-24.9 \%,-26.6 \%$ and $-12.0 \%)$ and $\operatorname{Lodz}(-17.4 \%,-11.5 \%$ and $-15.5 \%)$. After the lockdown, $\mathrm{PM}_{2.5}, \mathrm{PM}_{10}$ and $\mathrm{NO}_{2}$ concentrations also continued to decline. The only exception is the capital of the country, Warsaw, where $\mathrm{PM}_{2.5}$ and $\mathrm{PM}_{10}$ concentrations had slightly increased by $2.8 \%$ and $2.5 \%$ during the lockdown and decreased by $-25.2 \%$ and $-11.5 \%$, respectively. This may be due to the difficulty of isolating a whole large city within the short period of time, however, the gradual isolation has led to a significant reduction in pollutants after the lockdown. The process of $\mathrm{SO}_{2}$ changes was ambiguous with an increase during the period of isolation in Gdansk (80.4\%), Warsaw (33.1\%) and Lodz (12.4\%), and a decrease from $-5.1 \%$ (Wroclaw) to $-26.6 \%$ (Szczecin). This may be due to $\mathrm{SO}_{2}$ emissions from industrial processes, power plants and heating systems that continued to operate during the isolation period. However, the overall decline in air pollution indicates that significant air quality improvements can be expected if strict air quality control measures such as lockdowns are implemented. It should be noted that the data on the surface concentration of $\mathrm{NO}_{2}$ and $\mathrm{SO}_{2}$ are similar to the data obtained by Sentinel-5P.

No doubts that during and after the lockdown, there were trends towards a decrease in the concentration of pollutants, still, in the periods before the lockdown (Period 1 and Period 2), situation was the opposite: an increase in the concentration of pollutants was observed compared to 2019. There was a significant increase in the concentration of pollutants in the atmosphere of cities, this may be due to the high anthropogenic activity in 2020 connected with the high production of electricity, residential heating, industry and agriculture (Kaczmarczyk et al., 2020), which are likely to be affected by lockdown restrictions as well as by unfavorable meteorological conditions the least. According to the change in the meteorological parameters, presented in the Supplementary Materials (Figs. S1-S3), in March 2019, there was recorded a lower air temperature than in 2020 by about $5^{\circ} \mathrm{C}$, which may have led to a higher load on heat production for heating. In addition, lower wind speeds and a lower planetary boundary layer led to a decrease in the 
Table 4. Mean concentrations and relative change (\%) concentrations of ground-level $\mathrm{PM}_{2.5}, \mathrm{PM}_{10}, \mathrm{NO}_{2}$ and $\mathrm{SO}_{2}\left(\mu g \mathrm{~m}^{-3}\right.$ ) at $\mathrm{major}$ cities in Poland before, during and after lockdown.

\begin{tabular}{|c|c|c|c|c|c|c|c|c|c|c|c|c|c|}
\hline & \multicolumn{4}{|c|}{2019} & \multicolumn{4}{|c|}{2020} & \multicolumn{4}{|c|}{ Relative change (\%) } \\
\hline & & Period 1 & Period 2 & Period 3 & Period 4 & Period 1 & Period 2 & Period 3 & Period 4 & Period 1 & 1 Period 2 & Period 3 & Period 4 \\
\hline \multirow[t]{4}{*}{ Krakow } & $\mathrm{PM}_{2.5}$ & 25.4 & 30.8 & 33.0 & 24.8 & 22.2 & 30.4 & 31.4 & 16.6 & -12.4 & -1.3 & -5.1 & -33.0 \\
\hline & $\mathrm{PM}_{10}$ & 28.8 & 42.7 & 46.8 & 34.5 & 31.2 & 40.9 & 42.9 & 28.2 & 8.3 & -4.3 & -8.3 & -18.1 \\
\hline & $\mathrm{NO}_{2}$ & 37.7 & 42.1 & 42.4 & 39.9 & 40.8 & 30.5 & 34.4 & 27.1 & 8.3 & -27.6 & -18.8 & -32.1 \\
\hline & $\mathrm{SO}_{2}$ & 6.2 & 7.8 & 7.4 & 5.1 & 4.5 & 5.8 & 5.8 & 4.7 & -27.4 & -25.1 & -20.9 & -7.4 \\
\hline \multirow[t]{4}{*}{ Lodz } & $\mathrm{PM}_{2.5}$ & 16.6 & 18.9 & 23.4 & 16.3 & 17.7 & 23.7 & 19.3 & 10.2 & 6.3 & 25.4 & -17.4 & -37.1 \\
\hline & $\mathrm{PM}_{10}$ & 26.0 & 30.0 & 45.7 & 37.6 & 28.7 & 42.4 & 40.5 & 31.2 & 10.5 & 41.2 & -11.5 & -16.9 \\
\hline & $\mathrm{NO}_{2}$ & 19.8 & 20.8 & 31.9 & 31.6 & 23.5 & 27.2 & 27.0 & 19.9 & 18.9 & 30.7 & -15.5 & -37.0 \\
\hline & $\mathrm{SO}_{2}$ & 4.8 & 5.5 & 4.8 & 3.8 & 3.9 & 4.9 & 5.4 & 3.2 & -19.6 & -10.7 & 12.4 & -14.7 \\
\hline \multirow[t]{4}{*}{ Poznan } & $\mathrm{PM}_{2.5}$ & 15 & 16.9 & 24 & 17.9 & 19.7 & 26 & 18 & 10.1 & 31.3 & 53.8 & -25.0 & -43.6 \\
\hline & $\mathrm{PM}_{10}$ & 20.4 & 22.2 & 40.3 & 34.6 & 25.1 & 37.9 & 29.6 & 21.7 & 23.0 & 70.7 & -26.6 & -37.4 \\
\hline & $\mathrm{NO}_{2}$ & 20.5 & 24.4 & 19.6 & 19.3 & 19.5 & 19.7 & 17.5 & 14.1 & -4.9 & -19.3 & -10.7 & -26.9 \\
\hline & $\mathrm{SO}_{2}$ & 3.7 & 4.4 & 4 & 3.2 & 3.8 & 3.7 & 3.6 & 2.8 & 2.7 & -15.9 & -10.0 & -12.5 \\
\hline \multirow[t]{4}{*}{ Wroclaw } & $\mathrm{PM}_{2.5}$ & 16.2 & 18.5 & 27.8 & 19.9 & 15.1 & 26.8 & 20.9 & 12.9 & -6.9 & 44.7 & -24.9 & -35.1 \\
\hline & $\mathrm{PM}_{10}$ & 23.9 & 27.7 & 41.4 & 31.9 & 18.7 & 36.1 & 30.4 & 24.1 & -21.7 & 30.2 & -26.6 & -24.5 \\
\hline & $\mathrm{NO}_{2}$ & 21.1 & 24.9 & 28.5 & 26.5 & 24.6 & 25.1 & 25.0 & 20.3 & 16.3 & 0.9 & -12.0 & -23.6 \\
\hline & $\mathrm{SO}_{2}$ & 3.6 & 4.0 & 6.0 & 5.0 & 4.6 & 6.0 & 5.7 & 5.7 & 27.4 & 51.7 & -5.1 & 13.5 \\
\hline \multirow[t]{4}{*}{ Warsaw } & $\mathrm{PM}_{2.5}$ & 16.9 & 19.4 & 23.9 & 18.0 & 19.1 & 27.8 & 24.5 & 13.5 & 12.9 & 43.1 & 2.8 & -25.2 \\
\hline & $\mathrm{PM}_{10}$ & 26.0 & 28.0 & 39.9 & 32.1 & 23.1 & 40.7 & 40.9 & 28.4 & -11.4 & 45.1 & 2.5 & -11.5 \\
\hline & $\mathrm{NO}_{2}$ & 35.0 & 38.2 & 31.0 & 30.3 & 30.0 & 28.6 & 30.9 & 25.0 & -14.2 & -25.0 & -0.4 & -17.7 \\
\hline & $\mathrm{SO}_{2}$ & 4.0 & 3.9 & 2.6 & 2.3 & 4.0 & 4.8 & 3.4 & 2.8 & 0.2 & 22.4 & 33.1 & 20.4 \\
\hline \multirow[t]{4}{*}{ Gdansk } & $\mathrm{PM}_{2.5}$ & - & - & - & - & 22.2 & 28.7 & 16.0 & 8.9 & - & - & - & - \\
\hline & $\mathrm{PM}_{10}$ & 13.9 & 13.9 & 28.8 & 25.2 & 20.4 & 29.2 & 19.3 & 15.7 & 47.2 & 110.2 & -33.1 & -37.8 \\
\hline & $\mathrm{NO}_{2}$ & 15.2 & 13.1 & 18.8 & 16.7 & 15.3 & 20.2 & 15.3 & 11.3 & 0.7 & 54.0 & -18.5 & -32.5 \\
\hline & $\mathrm{SO}_{2}$ & 2.8 & 2.1 & 2.4 & 2.3 & 4.0 & 4.9 & 4.4 & 3.0 & 43.3 & 132.3 & 80.4 & 25.9 \\
\hline \multirow[t]{4}{*}{ Szczecin } & $\mathrm{PM}_{2.5}$ & 12.6 & 16 & 21.7 & 17.7 & 15.6 & 22.1 & 14 & 8.8 & 23.8 & 38.1 & -35.5 & -50.3 \\
\hline & $\mathrm{PM}_{10}$ & 15.9 & 19.9 & 31.6 & 33.5 & 19.4 & 31 & 21.4 & 18.1 & 22.0 & 55.8 & -32.3 & -46.0 \\
\hline & $\mathrm{NO}_{2}$ & 14.4 & 15.4 & 18.7 & 17.2 & 18.6 & 25.2 & 18.1 & 15.2 & 29.2 & 63.6 & -3.2 & -11.6 \\
\hline & $\mathrm{SO}_{2}$ & 4.2 & 2.4 & 6.4 & 5 & 2.9 & 4.9 & 4.7 & 5.5 & -31.0 & 104.2 & -26.6 & 10.0 \\
\hline
\end{tabular}

mixing height, thereby contributing to an increase in the concentration of pollutants. Although high precipitation results to the deposition of pollutants, it can also contribute to the hygroscopic growth of aerosols (He et al., 2016). According to Filonchyk et al. (2020a), westerly winds prevail in spring, which can also contribute to changes in the concentration of pollutants. However, a detailed analysis of changes in pollutants will require an in-depth study of differences in meteorological models over time, which is beyond the scope of this article.

Data from countries in the European Economic Area (EEA) show that the concentration of $\mathrm{NO}_{2}$ emitted mainly by road transport has decreased in many European cities where containment measures have been taken (EEA, 2020). A significant reduction in the concentration of pollutants has also been found in many regions of the world, indicating that isolation measures have a positive effect on air quality (Broomandi et al., 2020; Ginzburg et al., 2020; Jephcote et al., 2020; Liu et al., 2020; Zangari et al., 2020; Anil and Alagha, 2021; Islam et al., 2021; Sbai et al., 2021). In particular, measurements carried out at 129 monitoring stations located in the United Kingdom revealed average reductions in $\mathrm{PM}_{2.5}$ by $-16.5 \%$ and $\mathrm{NO}_{2}$ by $-38.3 \%$ (Jephcote et al., 2020). The reduction in emissions resulted to a $\mathrm{PM}_{2.5}$ decrease by $37 \%$ to $55 \%$ in four major cities in the Yangtze River Delta Region, China (Shanghai, Hangzhou, Nanjing, and Hefei) (Liu et al., 2020). In New York City, USA, $\mathrm{PM}_{2.5}$ and $\mathrm{NO}_{2}$ data obtained from 15 monitoring stations showed decreases in concentration by $-36 \%$ and $-51 \%$, respectively (Zangari et al., 2020).

The COVID-19 pandemic affects not only people's lives, but also has a direct impact on energy consumption and emissions of air pollutants both globally and regionally. During this time, shortterm reductions in energy consumption and emissions can lead to short-term improvements in air quality (Filonchyk et al., 2020b; Giani et al., 2020; Wang and Su, 2020; Zangari et al., 2020). 
One of the most obvious short-term effects of isolation from COVID-19 has been dramatic improvements in air quality, especially in some of the world's most polluted cities (Mahato et al., 2020; Rodríguez-Urrego and Rodríguez-Urrego, 2020; Singh and Chauhan, 2020; Wang et al., 2020). While air quality levels appear to be returning to pre-lockdown period in many parts of the world as stricter lockdown measures are lifted, this period has highlighted some of the benefits that can be brought by sustained reductions in air pollution.

\section{CONCLUSION}

The decrease in the level of anthropogenic activity caused by the national lockdown due to the COVID-19 pandemic has had a tangible positive effect on air quality in Poland. The results show a noticeable reduction in concentration of air pollutants during the isolation period, especially in Krakow, Szczecin, Poznan and Wroclaw. Decreases in $\mathrm{AOD}, \mathrm{NO}_{2}$ and $\mathrm{SO}_{2}$ values obtained from MODIS and TROPOMI were observed in almost all regions of the country. AOD values during the isolation period (Period 3 ) across the country decreased by $-47.9 \%$ in 2020 compared to the same period in 2019. In addition, satellite data for $\mathrm{NO}_{2}$ and $\mathrm{SO}_{2}$ also indicate a decrease in concentration of $-10.8 \%$ and $-25.6 \%$ during the COVID-19 restrictions. This decrease was due to the measures taken by the government to restrict the movement of people within and between countries, as well as to control industrial and business activity. Measures to contain the spread of the virus resulted in significant reductions in $\mathrm{PM}_{2.5}$ and $\mathrm{PM}_{10}$ concentrations from $-5.1 \%$ to $35.5 \%$ and from $-8.3 \%$ to $33.1 \%$ in major cities compared to previous years. In all the cities studied, there was a decrease in the ground-based concentration of $\mathrm{NO}_{2}$ by -0.4 to $18.8 \%$. These results show how the air quality in the country has improved due to the restrictive measures introduced during the COVID-19 pandemic. Moreover, the detailed role of meteorology has not been assessed or quantified in this study, and a more detailed study of the impact of meteorological conditions on air quality in Poland is recommended in future. This study has provided a basic scenario that in the future may help the correspondent authorities to develop pollution control policies, mainly connected to industrial and transport emission limits.

\section{ACKNOWLEDGEMENTS}

The work was financially supported by the National Key R\&D Program of China (2017YFB0504203), the China Postdoctoral Science Foundation Funded Project (2018M633605), the Postdoctoral Fund of Lanzhou Jiaotong University (2018BH03001).

\section{SUPPLEMENTARY MATERIAL}

Supplementary data associated with this article can be found in the online version at https://doi.org/10.4209/aaqr.200472

\section{REFERENCES}

Anil, I., Alagha, O. (2021). The impact of COVID-19 lockdown on the air quality of Eastern Province, Saudi Arabia. Air Qual. Atmos. Health 14, 117-128. https://doi.org/10.1007/s11869020-00918-3

Anttila, P., Tuovinen, J.P., Niemi, J.V. (2011). Primary $\mathrm{NO}_{2}$ emissions and their role in the development of $\mathrm{NO}_{2}$ concentrations in a traffic environment. Atmos. Environ. 45, 986-992. https://doi.org/10.1016/j.atmosenv.2010.10.050

Baldasano, J.M. (2020). COVID-19 lockdown effects on air quality by $\mathrm{NO}_{2}$ in the cities of Barcelona and Madrid (Spain). Sci. Total Environ. 741, 140353. https://doi.org/10.1016/j.scitotenv.2020. 140353

Biswas, K., Chatterjee, A., Chakraborty, J. (2020). Comparison of air pollutants between Kolkata and Siliguri, India, and its relationship to temperature change. J. Geovis. Spat. Anal. 4, 25. https://doi.org/10.1007/s41651-020-00065-4 
Broomandi, P., Karaca, F., Nikfal, A., Jahanbakhshi, A., Tamjidi, M., Kim, J.R. (2020). Impact of COVID-19 event on the air quality in Iran. Aerosol Air Qual. Res. 20, 1793-1804. https://doi.org/10.4209/aaqr.2020.05.0205

Burns, J., Hoffmann, S., Kurz, C., Laxy, M., Polus, S., Rehfuess, E. (2021). COVID-19 mitigation measures and nitrogen dioxide-A quasi-experimental study of air quality in Munich, Germany. Atmos. Environ. 246, 118089. https://doi.org/10.1016/j.atmosenv.2020.118089

Chakraborty, I., Maity, P. (2020). COVID-19 outbreak: Migration, effects on society, global environment and prevention. Sci. Total Environ. 728, 138882. https://doi.org/10.1016/j.scitot env.2020.138882

European Environment Agency (EEA) (2020). Air quality and COVID-19. https://www.eea. europa.eu/themes/air/air-quality-and-covid19

Filonchyk, M., Hurynovich, V., Yan, H. (2020a). Trends in aerosol optical properties over Eastern Europe based on MODIS-Aqua. Geosci. Front. 11, 2169-2181. https://doi.org/10.1016/j.gsf.20 20.03.014

Filonchyk, M., Hurynovich, V., Yan, H., Gusev, A., Shpilevskaya, N. (2020b). Impact assessment of COVID-19 on variations of $\mathrm{SO}_{2}, \mathrm{NO}_{2}, \mathrm{CO}$ and $\mathrm{AOD}$ over East China. Aerosol Air Qual. Res. 20, 1530-1540. https://doi.org/10.4209/aaqr.2020.05.0226

Giani, P., Castruccio, S., Anav, A., Howard, D., Hu, W., Crippa, P. (2020). Short-term and long-term health impacts of air pollution reductions from COVID-19 lockdowns in China and Europe: A modelling study. Lancet Planet. Health 4, e474-e482. https://doi.org/10.1016/S2542-5196(20) 30224-2

Ginzburg, A.S., Semenov, V.A., Semutnikova, E.G., Aleshina, M.A., Zakharova, P.V., Lezina, E.A. (2020). Impact of COVID-19 lockdown on air quality in Moscow. Dokl. Earth Sc. 495, 862-866. https://doi.org/10.1134/S1028334X20110069

Halkos, G., Tsilika, K. (2019). Understanding transboundary air pollution network: Emissions, depositions and spatio-temporal distribution of pollution in European region. Resour. Conserv. Recycl. 145, 113-123. https://doi.org/10.1016/j.resconrec.2019.02.014

Hoang, T., Tran, T.T.A. (2021). Ambient air pollution, meteorology, and COVID-19 infection in Korea. J. Med. Virol. 93, 878-885. https://doi.org/10.1002/jmv.26325

Islam, M.S., Tusher, T.R., Roy, S., Rahman, M. (2021). Impacts of nationwide lockdown due to COVID-19 outbreak on air quality in Bangladesh: A spatiotemporal analysis. Air Qual. Atmos. Health 14, 351-363. https://doi.org/10.1007/s11869-020-00940-5

Jephcote, C., Hansell, A. L., Adams, K., Gulliver, J. (2020). Changes in air quality during COVID-19 'lockdown' in the United Kingdom. Environ. Pollut. 272, 116011. https://doi.org/10.1016/j.env pol.2020.116011

Kaczmarczyk, M., Sowiżdżał, A., Tomaszewska, B. (2020). Energetic and environmental aspects of individual heat generation for sustainable development at a local scale-A case study from Poland. Energies 13, 454. https://doi.org/10.3390/en13020454

Krzysztofik, R., Kantor-Pietraga, I., Spórna, T. (2020). Spatial and functional dimensions of the COVID-19 epidemic in Poland. Eurasian Geogr. Econ. 61, 573-586. https://doi.org/10.1080/15 387216.2020.1783337

Lai, I.C., Brimblecombe, P. (2021). Long-range transport of air pollutants to Taiwan during the COVID-19 lockdown in Hubei Province. Aerosol Air Qual. Res. 21, 200392. https://doi.org/10.4 209/aaqr.2020.07.0392

Li, Z., Hu, Y., Chen, L., Wang, L., Fu, D., Ma, H., Liu, A. (2018). Emission factors of $\mathrm{NO}_{x}$, $\mathrm{SO}_{2}$, and PM for bathing, heating, power generation, coking, and cement industries in Shanxi, China: Based on field measurement. Aerosol Air Qual. Res. 18, 3115-3127. https://doi.org/10.4209/ aaqr.2018.08.0282

Liu, T., Wang, X., Hu, J., Wang, Q., An, J., Gong, K., Huang, C. (2020). Driving forces of changes in air quality during the COVID-19 lockdown period in the Yangtze River Delta region, China. Environ. Sci. Technol. Lett. 7, 779-786. https://doi.org/10.1021/acs.estlett.0c00511

Lyapustin, A., Wang, Y., Korkin, S., Huang, D. (2018). MODIS collection 6 MAIAC algorithm. Atmos. Meas. Tech. 11, 5741-5765. https://doi.org/10.5194/amt-11-5741-2018

Mahato, S., Pal, S., Ghosh, K.G. (2020). Effect of lockdown amid COVID-19 pandemic on air quality of the megacity Delhi, India. Sci. Total Environ. 730, 139086. https://doi.org/10.1016/j.scitote nv.2020.139086 
McGonigle, A.J.S., Thomson, C.L., Tsanev, V.I., Oppenheimer, C. (2004). A simple technique for measuring power station $\mathrm{SO}_{2}$ and $\mathrm{NO}_{2}$ emissions. Atmos. Environ. 38, 21-25. https://doi.org/ 10.1016/j.atmosenv.2003.09.048

Melkonyan, A., Kuttler, W. (2012). Long-term analysis of $\mathrm{NO}, \mathrm{NO}_{2}$ and $\mathrm{O}_{3}$ concentrations in North Rhine-Westphalia, Germany. Atmos. Environ. 60, 316-326. https://doi.org/10.1016/j.atmosen v.2012.06.048

Osička, J., Kemmerzell, J., Zoll, M., Lehotský, L., Černoch, F., Knodt, M. (2020). What's next for the European coal heartland? Exploring the future of coal as presented in German, Polish and Czech press. Energy Res. Soc. Sci. 61, 101316. https://doi.org/10.1016/j.erss.2019.101316

Pacheco, H., Díaz-López, S., Jarre, E., Pacheco, H., Méndez, W., Zamora-Ledezma, E. (2020). NO2 levels after the COVID-19 lockdown in Ecuador: A trade-off between environment and human health. Urban Clim. 34, 100674. https://doi.org/10.1016/j.uclim.2020.100674

Paraschiv, S., Paraschiv, L.S. (2019). Analysis of traffic and industrial source contributions to ambient air pollution with nitrogen dioxide in two urban areas in Romania. Energy Procedia 157, 1553-1560. https://doi.org/10.1016/j.egypro.2018.11.321

Rodell, M., Houser, P.R., Jambor, U.E.A., Gottschalck, J., Mitchell, K., Meng, C.J., Entin, J.K. (2004). The global land data assimilation system. Bull. Am. Meteorol. Soc. 85, 381-394. https://doi.org/ 10.1175/BAMS-85-3-381

Rodríguez-Urrego, D., Rodríguez-Urrego, L. (2020). Air quality during the COVID-19: PM2.5 analysis in the 50 most polluted capital cities in the world. Environ. Pollut. 266, 115042. https://doi.org/10.1016/j.envpol.2020.115042

Sas, A. (2021). Effect of the coronavirus epidemic on air traffic in Poland 2020, by airport. https://www.statista.com/statistics/1103925/poland-effect-of-the-coronavirus-epidemic-onair-traffic/

Sbai, S.E., Mejjad, N., Norelyaqine, A., Bentayeb, F. (2021). Air quality change during the COVID19 pandemic lockdown over the Auvergne-Rhône-Alpes region, France. Air Qual. Atmos. Health 14, 617-628. https://doi.org/10.1007/s11869-020-00965-w

Schindler, T.L. (2020). Reductions in Pollution Associated with Decreased Fossil Fuel Use Resulting from COVID-19 Mitigation. https://svs.gsfc.nasa.gov/4810 (accessed 11 June 2020).

Sher, E. (1998). Handbook of air pollution from internal combustion engines: Pollutant formation and control. Academic Press.

Siddiqui, A., Halder, S., Chauhan, P., Kumar, P. (2020). COVID-19 pandemic and city-level nitrogen dioxide $\left(\mathrm{NO}_{2}\right)$ reduction for urban centres of India. J. Indian Soc. Remote Sens. 48, 999-1006. https://doi.org/10.1007/s12524-020-01130-7

Singh, R.P., Chauhan, A. (2020). Impact of lockdown on air quality in India during COVID-19 pandemic. Air Qual. Atmos. Health 13, 921-928. https://doi.org/10.1007/s11869-020-00863-1

Somani, M., Srivastava, A.N., Gummadivalli, S.K., Sharma, A. (2020). Indirect implications of COVID-19 towards sustainable environment: An investigation in Indian context. Biores. Technol. Rep. 11, 100491. https://doi.org/10.1016/j.biteb.2020.100491

Suhaimi, N.F., Jalaludin, J., Latif, M.T. (2020). Demystifying a possible relationship between COVID-19. air quality and meteorological factors: Evidence from Kuala Lumpur, Malaysia. Aerosol Air Qual. Res. 20, 1520-1529. https://doi.org/10.4209/aaqr.2020.05.0218

Veefkind, J.P., Aben, I., McMullan, K., Förster, H., De Vries, J., Otter, G., Levelt, P.F. (2012). TROPOMI on the ESA Sentinel-5 Precursor: A GMES mission for global observations of the atmospheric composition for climate. air quality and ozone layer applications. Remote Sens. Environ. 120, 70-83. https://doi.org/10.1016/j.rse.2011.09.027

Wang, Q., Su, M. (2020). A preliminary assessment of the impact of COVID-19 on environmentA case study of China. Sci. Total Environ. 728, 138915. https://doi.org/10.1016/j.scitotenv.20 20.138915

Wang, Y., Wen, Y., Wang, Y., Zhang, S., Zhang, K.M., Zheng, H., Hao, J. (2020). Four-month changes in air quality during and after the COVID-19 lockdown in six megacities in China. Environ. Sci. Technol. Lett. 7, 802-808. https://doi.org/10.1021/acs.estlett.0c00605

Ye, X., Du, J., Gong, X., Na, S., Li, W., Kudva, S. (2021). Geospatial and semantic mapping platform for massive COVID-19 scientific publication search. J. Geovis. Spat. Anal. 5, 5. https://doi.org/ 10.1007/s41651-021-00073-y

Yunus, A.P., Masago, Y., Hijioka, Y. (2020). COVID-19 and surface water quality: Improved lake 
water quality during the lockdown. Sci. Total Environ. 731, 139012. https://doi.org/10.1016/j. scitotenv.2020.139012

Zangari, S., Hill, D.T., Charette, A.T., Mirowsky, J.E. (2020). Air quality changes in New York City during the COVID-19 pandemic. Sci. Total Environ. 742, 140496. https://doi.org/10.1016/j.sci totenv.2020.140496 